\title{
Review
}

Md Anzar Alam*, Mohd Aleemuddin Quamri, Ghulamuddin Sofi, Umme Ayman, Shabnam Ansari and Mariyam Ahad

\section{Understanding COVID-19 in the light of epidemic disease described in Unani medicine}

https://doi.org/10.1515/dmpt-2020-0136

Received July 21, 2020; accepted August 3, 2020; published online

September 22, 2020

\begin{abstract}
Unani system of medicine is based on the humoral theory postulated by Hippocrates, according to him the state of body health and disease are regulated by qualitative and quantitative equilibrium of four humours. Amraz-e-Waba is an umbrella term which is used in Unani medicine for all types of epidemics (smallpox, measles, plague, Hameer Saifi, influenza, Nipaha, Ebola, Zika, and 2019 novel coronavirus, etc.) mostly fatal in nature. The coronavirus disease 2019 (COVID-19) is a severe acute respiratory infection, and the pathogenesis and clinical features resemble with those of Nazla-e-Wabaiya (influenza) and Zatul Riya (pneumonia) which were well described many years ago in Unani text such as high-grade fever, headache, nausea and vomiting, running nose, dry cough, respiratory distress, alternate and small pulse, asthenia, foul smell from breath, insomnia, frothy stool, syncope, coldness in both upper and lower extremities, etc. The World Health Organization declared COVID-19 as a global emergency pandemic. Unani scholars like Hippocrates (370-460 BC), Galen (130-200 AD), Rhazes (865-925 AD), and Avicenna (980-1037 AD) had described four etiological factors for Amraz-e-Waba viz., change in quality of air, water, Earth, and celestial bodies, accordingly
\end{abstract}

*Corresponding author: Md Anzar Alam, MD, PhD, Department of Moalajat (Medicine), National Institute of Unani Medicine, Bangalore, 560091, India, Phone: +91 9916164662,

E-mail: dranzarnium@gmail.com. https://orcid.org/0000-00023548-8873

Mohd Aleemuddin Quamri and Mariyam Ahad, Department of Moalajat (Medicine), National Institute of Unani Medicine, Bangalore, India

Ghulamuddin Sofi, Department of IlmulAdvia (Pharmacology), National Institute of Unani Medicine, Bangalore, India

Umme Ayman, Department of Regimenal Therapy, National Institute of Unani Medicine, Bangalore, India

Shabnam Ansari, Department of Biotechnology, Natural Sciences, Jamia Millia Islamia University, New Delhi, India mentioned various preventive measures to be adopted during epidemics such as restriction of movement, isolation or "quarantena", and fumigation with loban (Styrax benzoin W. G. Craib ex Hartwich.), sandalwood (Santalum album L.), Zafran (Crocus sativus L.), myrtle (Myrtus communis L.), and roses (Rosa damascena Mill.) and use of vinegar (sirka) and antidotes (Tiryaq) as prophylaxis, and avoiding consumption of milk, oil, sweet, meat, and alcohol. This review focuses and elaborates on the concept, prevention, and probable management of COVID-19 in the light of Amraz-e-Waba.

Keywords: Amraz-e-Waba; antidotes; coronavirus disease; epidemic disease; fumigation; Unani medicine.

\section{Introduction}

The science of the Unani system of medicine is based on Hippocratic theory of four humours: sanguine, phlegm, yellow bile, and black bile [1]. Any disruption in the equilibrium of humours causes disease and thus the treatment seeks to restore balance by employing measures that counteract the deranged humours and temperament, etc. (preventive measures and including drugs) [2]. Furthermore, the Unani system of medicine also believes that Quwat-e-mudabbir-e-Badan (medicatrix-naturae) is the supreme force that regulates all the functions of the body and acts against the diseases [3]. There are three causes according to the doctrine of Unani medicine: bodily predisposition, environmental factors, and a mediating cause [4]. The environmental cause is the most common cause of an epidemic or pandemic or Nazla-e-Wabaiya [5]. Renowned Unani scholars like Hippocrates (370-460 BC), Galen (130-200 AD), Rhazes (865-925 AD), Avicenna (980-1037 AD) described that, there are four etiological factors responsible for Amraz-e-Waba (epidemic disease), i.e., change in quality of air, water, Earth, and celestial bodies [6, 7]. According to Avicenna (980-1037 AD), Humma-e-Waba (epidemic fever) is a very acute, fatal 
fever, which is caused due to infected air, and it spreads very rapidly among larger populations [8-10]. There is no direct description in Unani system of medicine about coronavirus in general and in particular coronavirus disease 2019 (COVID-19), but the clinical features of COVID-19 resemble with those of Nazla-e-Wabaiya, a type of Amraz$e$-Waba (epidemic disease) [11]. COVID-19 is an infectious disease caused by the newly discovered novel coronavirus. This disease was unknown until the outbreak began in Wuhan, China, in December 2019 [12]. The most common symptoms of COVID-19 are fever, tiredness, and dry cough. Some patients may have aches and pains, nasal congestion, runny nose, sore throat, or diarrhea and in case of serious illness develop difficulty in breathing. Older people and those with underlying medical conditions including high blood pressure, heart issues, or diabetes mellitus are more likely to develop serious illness [12, 13]. The World Health Organization has declared the COVID-19 as a pandemic and a global health emergency $[12,14]$. The number of cases of COVID-19 infection in the world is rising day by day. With the spread in many countries, general measures like isolation, social distancing, and routine use of masks and regular washing of hands are being propagated [12, 15]. Unani medicine places more emphasis on maintaining health and disease prevention along with the treatment.

\section{Methodology}

The concept of epidemic diseases (Amraz-e-Waba) has been surveyed from literature of Unani medicine such as Al-Havi Fit Tib (Liber continence) [7], Kitabul Mansoori [9], Kamil-Us-Sana (Liber regius) [10], Al-QanoonFit Tib (Canon of Medicine) [11], Zakheera Khvarazm Shahi (Treasure of Khvarazm Shah) [16], Kitab Al-Taisir [17], Akseer-e-Azam (Al-Akseer) [18], Hummiyat-e-Qanoon [8]. The modern concept of coronavirus in general and COVID19 in particular was appraised from internet sources such as PubMed, Medline, Scopus, ScienceDirect, Google Scholar, etc. [19-21]. The keywords used are Amraz-e$W a b a$, epidemic disease, coronavirus, antiviral, antioxidant, immunomodulator, and antipyretic.

\section{Concept of epidemic disease (Amraz-e- Waba)}

Unani medicine attributes infectious disease as the pathogen's success to the vulnerability of the organism to infection (host factors) due to humoral imbalance or dystemperament $[4,8,18,22]$. There are three sets of causes in Unani medicine: (i) bodily predisposition - humoral, temperamental or structural; (ii) external causes that are mainly environmental, and (iii) bodily relation causes that are necessary to induce change arising from the interaction of the first two sets $[11,18]$. The predisposing and external causes will share an agent to affect health status $[4,18]$. The environmental cause is the most common cause of an epidemic or pandemic $[4,5]$. Multiple weather changes in one season are less conducive to epidemics than many changes over several seasons, and this is not similar to water expansion $[4,6]$. These changes in air are either in its composition or qualities $[4,7]$. The change in composition happens when one of its components becomes excessive or rare, and this induces epidemics due to the putrefaction in the air that is similar to that occurring in a pond or stagnant water $[4,6,8]$. Air with high humidity is conducive to epidemics and putrefaction. Additionally, stagnant waters also become moldy $[4,11]$. A southerly summer increases epidemics [4].

Avicenna in canon of medicine described that the changes that occur in the air are similar to those of which occur in water, which is why the quality of the air changes to hot or cold and the constituents or temperament of air changes $[8,11]$. Due to these changes, changes in color and taste and putrefaction are produced. For example, changes in the taste and color of water occur, which develops foul smell and becomes infected $[8,18]$. Also remember that when the water is "pure", it is not infected until it comes in contact with infected particles (Ajsam-e-Arziya Khabeesa), and thus, it mixes with water and pollutes it $[8,9]$. Similar is the case with air. When the air is "pure", it is not infected, it becomes infected when "impure vapors" blend (combine) with it and turn the air into poor quality air $[8,10,18]$. The reason for this change generally is that when the wind travels from one place to another, it brings along infected air and particles with it [11, 18], for example, where there are dirty streams or putrefied corpses, like the air of the battlefield full of dead corpses or infected air due to an epidemic disease which were neither buried nor burnt $[8$, 16]. As a result of these unpleasant and infective changes in the air, the air of a good area (place) is spoiled. And this change in the air is not due to distant cause, but it is due to proximate cause $[8,11]$.

Beneath the ground, infection is caused due to various factors and we are unaware of its constituents [8]. These causes then enter air and water, polluting and infecting it. Those epidemic fevers that occur due to dry air are very less when compared to those which occur due to moist air $[8,9]$. In dry air, the production of bile is increased and hence it becomes the cause for greater incidences of bilious fever 
[11]. And epidemic fevers are produced due to "turbid" and "moistened air" [8]. Fevers are predominantly caused by moist air but they are less severe and are of longer duration because its substance is viscid and hence it resolves gradually $[8,9]$. During summers, due to scanty rainfall, fevers are rare but they are very severe and the duration is less, i.e., either the patient regains health quickly or dies very soon $[8,10]$. The best season is that which protects the physis and whose special temperament remains constant $[5,8,18]$. All of these changes are due to one of many astral (celestial) positions. The causes of these changes are principle causes, and distant cause is a few [8]. After this, from its weak heat, it affects the heart. The temperament of cardiopulmonary circulation or animal spirit becomes putrid, and the humours are putrefied which lie inside the heart, an abnormal temperature is formed and is spread to the whole body through blood vessels. As a result, epidemic fever is produced and spread to communities or species [8-10].

\section{Indicators that predict epidemic disease (Amraz-e-Waba)}

An epidemic in summer and in winters is predicted with two different sets of signs. Symptoms are those which appear at the start of Mausam-e-Khareef (autumn season) [8-11]. All these signs show that an epidemic is evolved like a cause gives the sign of any disease. If the direction of winds is towards the south and you feel viscid and turbidity in the air and the sky is cloudy such that it rains or when the sky is clear and there is no sign of rainfall, then we should be precautious that winter season has turned morbific [8-10]. But the signs of deuce and fatal epidemic of summers are that in spring season rains are less and cold is present $[5,8]$. And again in summers, south winds flow for few days until it become viscid and after that for more than a week, winds are clear. Then at night, in cold, patient feels extreme heat which means when heat is produced in the air it implies that the epidemic is here [8]. Now epidemic fever and smallpoxlike diseases prevail. Similarly, if there is not much heat during summers, "turbidity" is more in air and trees are covered with fog [8-10]. Then, this also is a sign of an upcoming epidemic. Similarly, if you see that the air changes many a times during the day. One day the air is clear and the sunrise is also clearly visible. But the very next day, air becomes turbid, and sunrise is hidden behind the fog $[8,9]$. Then the epidemic may be predicted in near future. These signs are produced along with the causes of the epidemic $[8$, $9,22]$. During these days, frogs are seen, and all insects and bacteria that are formed due to infections are increased.
Similarly, those animals/birds that are light or delicate leave their nests along with their eggs and fly away $[8,22]$.

The above observation was made by Hippocrates in his book "On epidemics" $[9,11]$. These indications may not concur with the view of climatic variation as we know it today. The rudiments of miasmatic theory or fetid air theory of epidemics augur well with it. The theory gave way to germ theory of infectious diseases, but the host factor and the environment are still considered important and necessary factors for spread of disease besides the virulence of the pathogen [7].

\section{Pathogenesis of COVID-19 in the light of humoral theory}

According to the Unani concept, infectious disease developed due to abnormal dominance of Hararat (hot), Ratoobat (moist), and Ajsam-e-Khabisha (microbes) [7-9, 23]. In Wuhan, during winter, moist environment increased the risk of viral infection [24]. Presently, season is changing into summer (hot) which also precipitates the spreads of microbes (e.g., viruses, bacteria, fungus) [8, 23, 25, 26]. Rhazi $[7,9]$ says that, peak summer along with rainy season is one of the most common causes of epidemic diseases. This observation implies that, Unani medicine promotes the elimination of moistness (dampness) from the body during "epidemic situation" with the help of some specific regimes which promotes the lessening of moisture that inhibit the growth of microbes (viruses) [8, 18, 22].

Predisposing factors include dominance of abnormal humours, contact to infected person during epidemic conditions, peak summer along with heavy rains or beginning of rainy season, moist air and direction of air from south to other direction, open orifice, scratch skin and membranes, weak immunity, moist temperament, migration from the place of epidemic, breath infected air, excessive coitus, vulnerable ages are child, adults than older age along with obese person, excessive intakes of alcohol, milk, sweet, meat, watery contain fruits, and oily products $[8-10,16,22]$.

\section{Clinical features of Amraz-e-Waba}

Clinical features of Amraz-e-Waba depend on the quality of humours, seasons, quality of air, the direction of air, physis, types of diet, habitants, ages, celestial bodies, contact of microbes (Ajsam-e-Khabeesha), etc. [8, 9, 22]. A number of clinical features arise during Amraz-e-Waba, such as high-grade fever, headache, nausea and vomiting, dry cough, running nose, pneumonia, hunger breathing, 
respiratory distress, alternate and small pulse, loss of appetite, foul smell from breath, dry tongue, asthenia, confusion, insomnia, rashes over the body, splenomegaly, abdominal pain, enlarged lymph nodes, sweating with bad odor, frothy stool, syncope, coldness in both upper and lower extremities, fatal death $[6-11,18,22]$.

\section{Preventive measures (Tahaffuzi Tadabeer)}

Unani medicine recognizes the impact of climate and environmental factors on human health. Temperament is the most basic concept of health promotion and disease prevention [1]. The Unani medicine system classics explicitly state that health care is superior to treatment $[5,11,18]$. During disease conditions, therapy is carried out using the opposite temperament nondrug (diet) and drug factors, whereas, for health maintenance, nondrug factors of the same temperament are often used $[2,3]$. Unani medicine puts particular emphasis on the six important factors (Asbab-e-Sitta Zarooriya) for health maintenance, i.e., ambient air, food and drink, bodily movement and repose, mental movement and repose, sleep and wakefulness, and evacuation and retention $[8,11]$.

If the air becomes contaminated and epidemical, one should take precaution by drying the body and adjusting the residence with substances that cool and humidify by their action - this is the correct action in epidemic - or carryout a warming action against the corrupting element. Pleasant and aromatic perfumes are the most effective in this regard, especially if they are antagonistic to the temperament favoring the epidemic $[4,8,18,22]$. In an epidemic, one should reduce excessive intake of air through ventilation and distribution $[4,5]$. Very often, the source of air distortion is from the ground; therefore, it is preferred to sit on sofas and seek well-aerated, high locations for residence [9, 22]. Frequently, the air itself is the source of distortion due to its mixing with neighboring contaminated air or an inexplicable atmospheric cause [4]. In this case, it is better to seek shelter in houses or "quarantena" that are surrounded by walls and bedrooms $[4,8]$. The incenses most suitable for treating distorted air are galingale (Cyperus longus L.), loban (Styrax benzoin $W$. G. Craib ex Hartwich.), myrtle (Myrtus communis L.), roses (Rosa damascena Mill.), and sandalwood (Santalum album L.) [9]. The use of vinegar during epidemics is protective [4, 22]. Hakeem Akbar Arzani (1772 AD) quotes that during the epidemic or pandemic, regular oral use of Roghan-e-Gao (cow ghee) along with externally massaged over the body is most effective [18].

\section{Shelters (Makan)}

Houses of patients with epidemic fever should be kept cool because cold temperature suppresses infection, and infection cannot occur without heat $[8,18]$. The house has to be cleaned regularly and air has to be purified $[8,9]$. In order to keep the house cool, cold temperament fruits such as Utruj (Citrus medica L.) and apple (Malus domestica L.), cold aromatous shrubs like Gul-e-Banafsa (Viola odorata L.), Gul-e-Nilofar (Nymphaea alba L.), Baid Mushk (Salix alba L.), and branches of neem (Azadirachta indica L.) are kept in the house [8]. Lakhlakha (inhalants) and Nazuhat (spray) prepared from cold fragrant fruits, Kafoor, Arq-eGulab, Arq-e-BaidMushk, Arq-e-Nilofar are to be kept at home, and it is best if there is a fountain at home $[8,9,11]$.

\section{Drugs (Advia)}

To a patient with epidemic fever, Qurs Kafoor and ruboob acting as coolants are given. Ma-ur-Rayeb (water of curd) is given to drink, buttermilk, Arq-e-Gulab, Aqueous of Paneer, vinegar to be mixed with water and given, cold water is also beneficial $[8,11,22]$. But if cold Sirka (vinegar) is given very often in heat, it irritates $[8,18]$. In severe cases, if there is a feeling of pressure below the ribs and dilatation is present, extremities turn cold, restlessness and delirium happens, then warm clothes should be worn that absorb the heat externally [8].

\section{Diet (Ghiza)}

Sour foods (Tursh Ghiza) are generally recommended but in less quantity, though use of meat is avoided, but, Halam, Qarees, Masoos are foods prepared with meat and vinegar (Sirka) or other sour food substance such as Sumaq (Rhus coriaria L.), Aab-e-Angur Kham (Vitis vinifera L.), Aab-e-Limu (Citrus limon L.), Aab-e-Anar (Punica granatum L.) are advised $[8,18,22]$. Mukhallilat (pickle made using sirka) especially "KibrMakhl" is very effective, and Hing (Ferula foetida L.) is also effective against infections; anorexic patients should be promoted to take food forcefully $[8,22]$.

\section{Air purification (Islah-e-Hawa)}

According to the health of the patient, dryness to be produced in the air so as to prevent infection $[8,22]$. Air purification can be carried out by the fumigation of some antiseptic drugs like Oodkham (Aquilaria agallocha Roxb.), Amber (Amberis grasea), Kundur (Boswellia serrata Roxb.), Mushk (Moschcus moschiferus L.), Qust Shirin (Sassurea lappa Clarke), Sandarus (Hymenaea verrucosa Gaertn.) Hing (Ferula foetida L.), 
Qaranfal (Syzygium aromaticum L.), Zafran (Crocus sativa L.), Chharela (Nardostachis jatamansi L.), Nagarmotha (Cyperus rotundus L.), Izkhar (Andopogam shaenarthus L.), Abhal (Juniperus communis L.), Waj (Acorus calamus L.), BadamTalkh (Prunus amygdalus Batsch) [8, 11, 18, 22]. Suggested use of Sirka (Acetic acid) and Hing (Ferula foetida L.) has also been suggested by Unani physicians as a spray to prevent infection $[8,9,18,22]$.

The following drugs either single or in combination are recommended to use more often as Bakhoor (incenses or fumigation) to prevent the microbes and their infection such as Sandal (S. album L.), Kafoor (Cinnamomum camphora L.), Post Anar (P. granatum L.), Tuffa (M. domestica L.), Aas (M. communis L.), Bahi (Cydonia oblonga Miller.), Abnoos (Diospyros ebenum J. Koenig ex Retz.), Sazaj (Cinnamomum tamala L.), Jhau (Tamarix dioica Roxb.) [8, 22].

\section{Regimes (Tadabeer)}

To prevent epidemics, "Ratoobat-e-Fazila" (morbid humours) from the body should be expelled through Qai (vomiting) and Ishal (purgation with the help of Cassia angustifolia L.) and Fasd (venesection) and other essential regimens of Asbab-eSittah Zaruriyah (six prerequisites for existence) which produces dryness in the body $[8,9,18,22]$, including drugs and reduce food intake, avoiding Riayzat (exercise) and Hammam (bathing). Moreover, use of drinks restricted to avoid moistness in the body $[8,9,22]$. An antidotes like Tiryaq-e-Mashridutes,Tiryaq-e-Wabai or Gil-e-Armani are recommended by Jalinus to use as prophylactic medicine before the being of the air born infection as (Hawa-e-Wabai) [8, 18, 22].

\section{Management of the epidemic through Unani medicine}

In the Unani system of medicine, there is no description of coronavirus, but the clinical features are similar to those of Amraz-e-Waba (epidemic disease) [9]. In Unani literature well description available for epidemic condition and their management $[8,9,22]$. Rhazi and Avicenna suggested following restriction of movements, reduced diet intake, and especially to avoid meat, oil, milk products, and alcohol during epidemics $[11,18]$. Protection of vital organs (heart, lungs, brain, and liver) is compulsory [6]. Use antidotes, especially during epidemic conditions [8, 18]. Some antidotes which have been described in Unani literature, such as Tiryaq-e-Wabai, Tiryaq-e-Farooq, Tiryaq-eArba,Tiryaq-e-Nazli, Tiryaq-e-Mashridutes, Qurs Zahar Mohra, etc., are used as prophylactics and therapeutics [911, 27].

\section{Principles of treatment}

Principle of treatment based on "quarantena", protect the vital organs, exhilarants and cardiac tonics, antidotes, antipyretic and laxative [8, 11, 18, 22].

\section{Situational management of the epidemic}

Various drugs or formulation that can be used are follows:

- During high-grade fever, Joshandah Humma (10 g) along with Sharbat Unnab $20 \mathrm{~mL}$ should be used and KhamirahMarvareed $5 \mathrm{~g}$ [8, 9, 27]. Excess use of Arqiyat like Kiyorah, Arq-e-Sandal, Arq-e-Gulab, Arq-e-Gaozaban, Arq-e-Kasni [11, 18, 27].

- During respiratory distress (TanghiTanaffus), LauqSapistan along with Sharbat-e-Zoofa Murakkab and Tiryaq-e-Nazli will be effective. Steam with Arq-e-Ajeeb which promotes the breathing easily due to vasodilatation activity and also reported for antiseptic activity [8-11, 18, 27].

- $\quad$ During Gastrointestinal Tract (GIT) disturbance, Tiryaqe-Pechees along with Jawarish Amla are recommended [27].Use of Qurs Malti Basant and Amla Murabba will be effective along with coconut water [8-11, 18, 27].

- For Daf-e-Sammiyat or immune boost, use of antidotes will be effective: Qurs Zaharmohra, Habbe Jadwar, Tiryaq-e-Wabai, Tiryaq-e-Farooq, Tiryaq-e-Arba,Tiryaq-e-Nazli, etc. [8-11, 18, 27].

- For antistress and calming effect, Khamira Sandal, Khamira Marvareed, Khamira Abresham, Dawaul Misk Barid, Qurs Zahar Mohra, etc. are used [8-11, 18, 27].

- Famous Unani formulations: There are various Unani formulations which have been described in Unani literature for the management of infectious disease especially during "Waba" in the form of Joshandah, Safoof, Majoon, Khamira which acts as general tonic (Muqavvi Badan), cardiotonic (Muqavi Qalb), expectorant (Munaffise Balgham), antipyretic (Dafe Humma), blood purifier (Musaffi Dam), etc. [8, 9, 11, 27]. Some of them are named as Joshandah Nazla, Majoon Ushba, Majoon Chobchini, Khamira Sandal, Khamira Marvareed, Qurs Zahar Mohra, Habbe Jadwar, Tiryaq-e-Wabai, Tiryaq-e-Farooq, Tiryaq-e-Arba, Tiryaq-e-Nazli, Tiryaq-e-Ufai, Qurs Kafoor, and Gile Armani along with vinegar, etc. [8-11, 16, 18, 22, 27].

The above mentioned strategies for management of epidemics like COVID-19 make it necessary as when to initiate the specific drugs. It is summarized in the form of (Table 1) that briefs about the management at various stages of COVID-19 [12, 13]. 
Table 1: Described interventions for various stages of COVID-19 in the light of Unani medicine.

\begin{tabular}{|c|c|c|}
\hline S. No & Group of peoples [13] & Proposed intervention $[12,13]$ \\
\hline 1 & $\begin{array}{l}\text { Unexposed } \\
\text { asymptomatic group }\end{array}$ & $\begin{array}{l}\text { For maintenance of health, Unani medicine specially emphasized on the modulation of six essential factors } \\
\text { (Asbab-e-Sitta Zarooriya), i.e., air, food and drink, bodily movement and repose, psychic movement and } \\
\text { repose, sleep and wakefulness, and evacuation and retention, and also use of Tiryaq-e-Wabai as } \\
\text { prophylaxis. }\end{array}$ \\
\hline 2 & $\begin{array}{l}\text { Exposed asymptomatic } \\
\quad \text { (quarantined) }\end{array}$ & $\begin{array}{l}\text { Home stay, air purification with Loban or SaadKofi, use of Joshandah (Unnab, Sapistan, Bahidana, Mulethi, } \\
\text { Gilo, Zanjbeel, Filfil Daraj) along with Khameera Marwareed), and inhalation with Arq-e-Ajeeb. }\end{array}$ \\
\hline 3 & $\begin{array}{l}\text { With mild COVID-19 } \\
\text { symptoms }\end{array}$ & $\begin{array}{l}\text { Use Joshandah (Mulethi, Gilo, Tulsi, Kalonji, Zanjbeel, Filfil Daraj, Chiraita, Shahtara) along with Khameera } \\
\text { Marwareed, Habb-e-Bukhar and inhalation with Arq-e-Ajeeb. }\end{array}$ \\
\hline 4 & $\begin{array}{l}\text { With moderate to } \\
\text { severe COVID-19 } \\
\text { symptoms }\end{array}$ & $\begin{array}{l}\text { Use Joshanda (Mulethi, Gilo, Tulsi, Zanjbeel, Filfil Daraj, Chiraita, Shahtara, Afsanteen, Zafran) along with } \\
\text { Khameera Marwareed, Habbe-e-Bukhar, Habb-e-Surfa, Chaiwanprash and inhalation with Arq-e-Ajeeb. }\end{array}$ \\
\hline
\end{tabular}

COVID-19, coronavirus disease 2019.

Certain formulations which are acclaimed for managing epidemics with flu-like symptoms are described as follows:

- Joshandah Nazla Wabaiya: It has been used since centuries for the management of respiratory disorders and pyrexia of unknown origin $[8,11,27]$. It has antioxidant, immunomodulator, antipyretic, antiviral, antiinflammatory, and expectorant activity. Its ingredients are as following with reported actions (Table 2) [28, 53].

- Joshandah Sual: It is based on polyherbal formulation, which contains 11 ingredients. It has antioxidant, immunomodulator, antipyretic, antiviral, antiinflammatory, and expectorant activity. Its ingredients are as following with reported actions (Table 3). [2830, 37-40, 50-92].

- Method of use: As decoction twice a day for 7-14 days, and decoction can be taken with Sharbat-e-Unnab or honey (excepts diabetes patients).

- Tiryaq-e-Wabai: It is based on three ingredients which is especially used during epidemic condition and described by renowned Unani scholars Rhazes, Majusi, Avicenna, Ismail Jorjani, Hakim Azam Khan, etc. [7-11, 16, 18]. It has antioxidant, immunomodulator, antipyretic, antiviral, antiinflammatory, and expectorant activity. Its ingredients are as following with reported actions (Table 4). [93-108]. It is used in the form of $3 \mathrm{~g}$ Safoof (powder) thrice a day with Arq-eKiyora for 7-14 days.

- Arq-e-Ajeeb: Arq-e-Ajeeb is a liquid preparation obtained by mixing Kafoor, Jauhar-e-Pudina, and Jauhar-e-Ajwayin at room temperature in the quantity given below (Table 5) [109, 110]. It is prepared by taking all the three ingredients of pharmacopeial quality. Crush them separately to make their coarse powder, then mix as per composition of formulations in an air tight glass container, and allow liquefying and filtering. When the transparent homogenous liquid is obtained, fill it in moisture-free glass bottles [109, 110]. The drug can be taken orally with water, applied locally, as well as in the steam $[109,110]$.

Table 2: Scientific report and details of the ingredients of Joshandah Nazla Wabaiya for potential use in COVID-19.

\begin{tabular}{|c|c|c|c|c|c|c|}
\hline S. No. & Unani name & Botanical name & $\begin{array}{l}\text { Useful } \\
\text { parts }\end{array}$ & Weight & Pharmacological activities & References \\
\hline 1 & Unnab & Ziziphus jujube Mill. & Fruit & 5 Adad & Antiviral, antioxidant, immunomodulator & {$[28-30]$} \\
\hline 2 & Sapistan & Cordia myxa L. & Fruit & 9 Adad & $\begin{array}{l}\text { Antioxidant, immunomodulator, hypoglycemic, antitussive, } \\
\text { analgesic }\end{array}$ & [31-33] \\
\hline 3 & Bahidana & Cydonia oblonga Mill. & Seeds & $3 \mathrm{~g}$ & Antiviral, antiallergic, antioxidant, antimicrobial & {$[34-36]$} \\
\hline 4 & GuleBanafsa & Viola odorata L. & Flower & $7 \mathrm{~g}$ & Antioxidant, hepatoprotective, antibacterial, hypnotic, antiviral & {$[37-40]$} \\
\hline 5 & Khubazi & Malva sylvestris $\mathrm{L}$. & Seeds & $5 \mathrm{~g}$ & Antiviral, antioxidant immunomodulator & [41-43] \\
\hline 6 & Khatmi & Althea officinalis $\mathrm{L}$. & Seeds & $5 \mathrm{~g}$ & $\begin{array}{l}\text { Antioxidant immunomodulator, antibacterial, antiviral, } \\
\text { antitussive, bronchiodilator }\end{array}$ & [44-49] \\
\hline 7 & Mulethi & Glycyrrhiza glabra L. & Root & $5 \mathrm{~g}$ & $\begin{array}{l}\text { Anticoronavirus activity, antiviral, antimicrobial, antioxidant, } \\
\text { antiinflammatory activities. }\end{array}$ & [50-53] \\
\hline
\end{tabular}

Adad, piece/no.; COVID-19, coronavirus disease 2019. 
Table 3: Scientific report and details of the ingredients of Joshandah Sual for potential use in COVID-19.

\begin{tabular}{|c|c|c|c|c|c|c|}
\hline S. No. & Unani name & Botanical name & $\begin{array}{l}\text { Useful } \\
\text { parts }\end{array}$ & Weight & Pharmacological activities & References \\
\hline 1 & Mulethi & Glycyrrhiza glabra L. & Root & $5 \mathrm{~g}$ & $\begin{array}{l}\text { Anticoronavirus activity, antiviral, antimicrobial, antioxidant, } \\
\text { antiinflammatory activities }\end{array}$ & {$[50-53]$} \\
\hline 2 & Gilo & $\begin{array}{l}\text { Tinospora cordifolia } \\
\text { willd. }\end{array}$ & Stem & $9 \mathrm{~g}$ & $\begin{array}{l}\text { Antiviral, immunomodulator, antioxidant, analgesic, antipy- } \\
\text { retic activity }\end{array}$ & {$[54-57]$} \\
\hline 3 & Tulsi leaves & Oscimum sanctum L. & Leaves & $5 \mathrm{~g}$ & $\begin{array}{l}\text { Antiviral, analgesic, antipyeretic, immunomodulator, } \\
\text { antipneumonia. }\end{array}$ & [58-63] \\
\hline 4 & Shoneez & Nigella sativa $\mathrm{L}$. & Seeds & $2 \mathrm{~g}$ & $\begin{array}{l}\text { Antiviral, immunomodulator, antioxidant, antimicrobial, anal- } \\
\text { gesic, antiinflammatory, antipyretic, bronchodilator activity }\end{array}$ & {$[64-69]$} \\
\hline 5 & Zanjbeel & $\begin{array}{l}\text { Zingiber officinale } \\
\text { Roscoe }\end{array}$ & Rhizome & $1 \mathrm{~g}$ & $\begin{array}{l}\text { Antiviral, antioxidant, immunomodulator, antimicrobial, anal- } \\
\text { gesic, antiinflammatory, cough suppressing and broncho- } \\
\text { dilator activity }\end{array}$ & {$[70-76]$} \\
\hline 6 & FilfilDaraz & Piper longum L. & Fruit & $2 \mathrm{~g}$ & $\begin{array}{l}\text { Antiviral, analgesic, antipyretic, immunomodulator, anti- } \\
\text { asthamatic activity. }\end{array}$ & {$[77-81]$} \\
\hline 7 & Unnab & Ziziphus jujube Mill. & Fruit & 5 Adad & $\begin{array}{l}\text { Antiviral, antioxidant, immunomodulator, antiasthamatic, } \\
\text { cardio protective activity. }\end{array}$ & $\begin{array}{l}{[28-30,} \\
82,83]\end{array}$ \\
\hline 8 & GuleSurkh & Rosa damascena Mill. & Flowers & $7 \mathrm{~g}$ & $\begin{array}{l}\text { Antiviral, analgesic, antiinflammatory, antioxidant, } \\
\text { hepatoprotective }\end{array}$ & {$[84-86]$} \\
\hline 9 & GuleBanafsa & Viola odorata $\mathrm{L}$. & Flowers & $7 \mathrm{~g}$ & $\begin{array}{l}\text { Antioxidant, hepatoprotective, antibacterial, hypnotic effect, } \\
\text { antiviral. }\end{array}$ & [37-40] \\
\hline 10 & Chiraita & Swertia chirata L. & $\begin{array}{l}\text { Whole } \\
\text { plant }\end{array}$ & $7 \mathrm{~g}$ & Antiviral, antipyretic, antioxidant, analgesic. & [87-89] \\
\hline 11 & Shahtara & Fumaria officinalis L. & $\begin{array}{l}\text { Whole } \\
\text { plant }\end{array}$ & $7 \mathrm{~g}$ & Analgesic, antipyretic, antioxidant, diuretic, antimicrobial. & [90-92] \\
\hline
\end{tabular}

COVID-19, coronavirus disease 2019.

Table 4: Scientific report and details of the ingredients of Tiryaq-e-Wabai for potential use in COVID-19.

\begin{tabular}{|c|c|c|c|c|c|c|}
\hline S. No. & Unani name & Botanical name & Useful parts & Weight & Pharmacological activities & References \\
\hline 1 & Sibr & Aloe barbedensis $\mathrm{L}$. & Pulp & $2 \mathrm{~g}$ & Antiviral, antipyretic, antioxidant, immunomodulator & [93-97] \\
\hline 2 & Zafran & Crocus sativus L. & Stamen & $1 \mathrm{~g}$ & $\begin{array}{l}\text { Antiviral, antioxidant, immunomodulator, bronchodilator, } \\
\text { cardio protective activity }\end{array}$ & [98-102] \\
\hline 3 & Murmukki & $\begin{array}{l}\text { Commiphora myrrha } \\
\text { (Nees) }\end{array}$ & Gum & $1 \mathrm{~g}$ & $\begin{array}{l}\text { Analgesic, anti-inflammatory, antioxidant, } \\
\text { immunomodulator, hepatoprotective, antimicrobial. }\end{array}$ & [103-108] \\
\hline
\end{tabular}

COVID-19, coronavirus disease 2019.

Table 5: Unani description for Arq-e-Ajeeb during Amraz-e-Waba.

\begin{tabular}{llllll}
\hline S. No. & Unani name & Botanical name & Useful parts & Weight & Indications in Unani pharmacopeia [109, 110] \\
\hline 1 & Kafoor & Cinnamomum camphora L. & Camphor & $2 \mathrm{~g}$ & Nazla, Zukham, Sual, WajaulBatan, Ghisyan, Qai, Haiza, \\
2 & Jauhar-e-Pudina & Mentha arvensis L. & Menthol & $2 \mathrm{~g}$ & Zaheer, Lasa waLadag, Hisasia/Arjiyyah, WajaulMafasil, Suda. \\
3 & Jauhar-e-Ajwayin & Trachyspermum ammi L. & Thymol & $1 \mathrm{~g}$ & \\
\hline
\end{tabular}

\section{Discussion}

The Covid-19 infection is pandemic caused by a novel coronavirus a new strain of virus in humans belong to beta coronovirdea family; basically it affects the lungs and causes severe acute respiratory symptoms, and the virus hosts ACE2 receptors in the lungs and other parts of the body including kidney [111]. The symptoms of COVID-19 may range from mild, moderate to severe; around $86 \%$ of cases usually reported moderate symptoms of fever, dry cough, sore throat, and diarrhea and among severely infected cases, respiratory and multiorgan failure [15, 24]. 
Since Unani medicine treats it as "Amraz-e-Waba" or "Nazla-e-Wabaiya" that spreads through air, the same has been validated recently $[8,9,11]$. The droplets in microns settle in the air after a longer time of $10 \mathrm{~min}$ [111-114]. The preventive measures are well defined which are collectively called as measures of social distancing [115]. The measures that are mentioned in terms of sheltering in Unani are included for social distancing. Its management has been two pronged in Unani medicine [8-11, 22]. One is to revert the air quality to a pure form, i.e., to decontaminate the places of contact of the virus and the other is to manage the person who has contracted the disease [14]. Management is followed for febrile persons with upper respiratory tract (URT) symptoms in whom the formulations are used that are effective in flu patients [116]. Moreover, these formulations have got reported antiviral actions. The ingredients of the exemplified formulations have shown to be antiviral, antioxidant, immunomodulator, and antipyretic activities. Though the studies are preclinical but reports suggest their usefulness as antiviral. The patients who develop the signs for respiratory distress know drugs with immunomodulatory (Mulethi, Gilo, Asgand, Tulsi, Spirulina, Zafran, Sibr/Aelwa, Kalonji) [117118] effect are useful if treated quickly. The cytokine storms caused by the virus cannot be arrested by immune stimulants that may aggravate the condition and prove fatal, but immune suppressants or modulator immune responding drugs are of some help. The various ingredients in these formulations especially Sibr (Aloe barbedensis L.), Zafran (Crocus sativus L.), and Murmakki (Commiphoramyrrha (Nees)) will definitely be of help [119]. Some drugs like Zafran, Tulsi, Chaube Zard, Neem have been reported as thrombolytics also [120-122]. It may be a matter of time when these drugs are developed as a measure for management for COVID-19.

\section{Conclusions}

The above review showed the potential to cure the drugs commonly called galenicals from the ancient practitioner's armamentarium. It is hoped that further research on these will pave a way forward to arrest such epidemics.

\section{Highlights}

- Coronavirus disease 2019 (COVID-19) has been declared a global emergency by the World Health Organization.

- According to Unani literature, COVID-19 is a type of Amraz-e-Waba or Nazla-e-Wabaiya.
- Amraz-e-Waba are contagious, and some of them spreads rapidly, and are fatal also.

- People with malign humours and diminished immunity are more susceptible to Amraz-e-Waba.

- During Amraz-e-Waba, social distancing, restriction of movement, use of disinfectants, and fumigation and use of vinegar, and anti-dotes as prophylaxis.

Research funding: None declared.

Author contributions: Study concept and drafting: Md Anzar Alam; critical revision for imperative rational content: Mohd Aleemuddin Quamri, Editing: Ghulamuddin Sofi, and reference collected by Umme Ayman, Shabnam Ansari, and Mariyam Ahad.

Competing interests: Authors state no conflict of interest.

\section{References}

1. Ahmed SI. Introduction to Al-Umur-Al-Tabi'Yah. New Delhi: Central Council for Research in Unani Medicine New Delhi. Ministry of Health \& Family Welfare, New Delhi: Government of India; 2009. pp. 75-142.

2. Alam MA, Quamri MA, Sofi G, Tarique BM. Understanding hypothyroidism in Unani medicine. J Integr Med 2019;17:387-91.

3. Ansari AH, Zulkifle M, Ali M. An analytical study of concordance between mizaj and diseases in adult patients of NIUM hospital Bangalore. Anc Sci Life 2010;30:7-11.

4. Abu-Asab M, Amri H, Micozzi MS, Rochester VT. Avicenna's medicine: a new translation of the 11th-century canon with practical applications for integrative health care. Toronto: Healing Arts Press; 2013.

5. Kabeeruddin M. Kulliyat-e-Qanoon. New Delhi: Aejaz Publishing House, India; 2006.

6. Samaqandi AN. Sharah-e-Asbab wa Alamat. (Urdu translation by Allama Hakeem Kabeeruddin). New Delhi: Aejaz Publishing House, India; 2007. pp. 499-516.

7. Razi AMIZ. Kitab al Hawi. New Delhi: Central Council for Research in Unani medicine New Delhi. Ministry of Health \& Family Welfare, Government of India; 2008, vol 17. pp. 9-36.

8. Kabeeruddin HM. Hummiyat-e-Qanoon. Part-II. New Delhi: Central Council for Research in Unani medicine New Delhi. Ministry of Health \& Family Welfare, Government of India; 2009. pp. 39-47.

9. Razi AMBZ. KitabulMansoori. (Urdu translation). New Delhi: Central Council for Research in Unani Medicine New Delhi. Ministry of Health \& Family Welfare, Government of India; 1991. pp. 174-7.

10. Majoosi AIA. Kamilus Sanaa. (Urdu translation by Gulam Hasnain Kantoori). New Delhi, India: Idara Kitab Us Shifa; 2010, vol $1 \& 2$. pp. 620-1.

11. Sina I. Al Qanoon fit Tib. (Urdu translation by Kantoori GH). New Delhi, India: Idara Kitab Us Shifia; 2010, vol 4. pp. 1206-7.

12. Guidelines for Unani practitioners for COVID 19. Available from: https://www.ayush.gov.in/docs/unani-guidelines.pdf [Accessed 15 Jul 2020]. 
13. Rastogi S, Pandey DN, Singh RH. COVID-19 pandemic: a pragmatic plan for Ayurveda intervention. J Ayurveda Integr Med 2020 Apr 23. https://doi.org/10.1016/j.jaim.2020.04.002.

14. Hassan SA, Sheikh FN, Jamal S, Ezeh JK, Akhtar A. Coronavirus (COVID-19): a review of clinical features, diagnosis, and treatment. Cureus 2020;12:e7355.

15. Bedford J, Enria D, Giesecke J, Heymann DL, Ihekweazu C, Kobinger G, et al. COVID-19: towards controlling of a pandemic. Lancet 2020 Mar 17 https://doi.org/10.1016/S0140-6736(20) 30673-5.

16. Jurjani AHI. Zakhirah KhwarzamShahi. (Urdu translation by Khan HH). Part-V. New Delhi: IdaraKitab-us-Shifa, India; 2010:94 p.

17. Zuhr I. Kitab Al-Taiseer fi' Al-Midawa wo Al-Tadbeer. Urdu Translation. New Delhi: Central Council for Research in Unani Medicine New Delhi. Ministry of Health \& Family Welfare, Government of India; 1986:140-70 pp.

18. Khan HMA. Akseer-e-Azam. (Urdu translation by Allama Kabeeruddin). New Delhi: IdaraKitabusShifa, India; 2011:916-20 pp.

19. Rothan HA, Byrareddy SN. The epidemiology and pathogenesis of coronavirus disease (COVID-19) outbreak. J Autoimmun 2020 May;109:102433.

20. Zhang Y, Xu J, Li H, Cao B. A novel coronavirus (COVID-19) outbreak: a call for action. Chest 2020 Apr;157:e99-e101.

21. Matthay MA, Aldrich JM, Gotts JE. Treatment for severe acute respiratory distress syndrome from COVID-19. Lancet Respir Med 2020;8:433-4.

22. Qamari AMH. Ghina Muna (Urdu translation Minhajul Ilaj). New Delhi: Central Council for Research in Unani Medicine New Delhi. Ministry of Health \& Family Welfare, Government of India; 2008: 584-9 pp.

23. Rushd I. Kitab ul Kulliyat. (Urdu translation), 2nd ed. New Delhi: Central Council for Research in Unani Medicine New Delhi. Ministry of Health \& Family Welfare, Government of India; 1987: 81-8 pp. 439.

24. Cui HT, Li YT, Guo LY, Liu XG, Wang LS, Jia JW, et al. Traditional Chinese medicine for treatment of coronavirus disease 2019: a review. Tradit Med Res 2020;5:65-73.

25. Stewart PD. Seasonality and selective trends in viral acute respiratory tract infections. Med Hypotheses 2016 Jan;86: 104-19.

26. Gardner EG, Kelton D, Poljak Z, Van Kerkhove M, von Dobschuetz $\mathrm{S}$, Greer AL. A case-crossover analysis of the impact of weather on primary cases of Middle East respiratory syndrome. BMC Infect Dis 2019;19:113.

27. Kabeeruddin A. Biyaz-e-Kabeer. Hyderabad Dakkan, India: Hikmat Depo; 1935, vol I\& II:11-2 p. 13-9.

28. Hong EH, Song JH, Kang KB, Sung SH, Ko HJ, Yang H. Antiinfluenza activity of betulinic acid from Zizyphus jujuba on influenza A/PR/8 virus. Biomol Ther (Seoul) 2015 Jul;23: 345-9.

29. Zare-Zardini H, Tolueinia B, Hashemi A, Ebrahimi L, Fesahat F. Antioxidant and cholinesterase inhibitory activity of a new peptide from Ziziphus jujuba fruits. Am J Alzheim Dis Other Dementias 2013;28:702-9.

30. Chi A, Kang C, Zhang Y, Tang L, Guo H, Li H, et al. Immunomodulating and antioxidant effects of polysaccharide conjugates from the fruits of Ziziphus Jujube on chronic fatigue syndrome rats. Carbohydr Polym 2015;122:189-96.
31. Afzal M, Obuekwe C, Khan AR, Barakat H. Antioxidant activity of Cordia myxa L. and its hepatoprotective potential. EJEAF Che 2007;8:2236-42.

32. Ali WR, Al-Asady ZT, Ibrahim AA. Immunomodulatory of Cordia myxa (L.) aqueous extract fruit in immunized mice with hydatid cyst fluid. J Nat Sci Res 2015;5:75-83.

33. Salimimoghadam S, Ashrafi A, Kianidehkordi F, Najafzadehvarzi H. Hypoglycemic, antitussive and analgesic effects of nanoparticles of Cordia myxa fruits extract. Int J Pharm Investig 2019;9:205-9.

34. Hamauzu Y, Yasui H, Inno T, Kume C, Omanyuda M. Phenolic profile, antioxidant property, and anti-influenza viral activity of Chinese quince (Pseudocydonia sinensis Schneid.), quince (Cydonia oblonga Mill.), and apple (Malus domestica Mill.) fruits. J Agric Food Chem 2005;53:928-34.

35. Shinomiya F, Hamauzu Y, Kawahara T. Anti-allergic effect of a hotwater extract of quince (Cydonia oblonga). Biosci Biotechnol Biochem 2009;73:1773-8.

36. Fattouch S, Caboni P, Coroneo V, Tuberoso Cl, Angioni A, Dessi S, et al. Antimicrobial activity of Tunisian quince (Cydonia oblonga Miller) pulp and peel polyphenolic extracts. J Agric Food Chem 2007 Feb 7;55:963-9.

37. Jamshed H, Siddiqi HS, Gilani AU, Arslan J, Qasim M, Gul B. Studies on antioxidant, hepatoprotective, and vasculoprotective potential of Viola odorata and Wrightia tinctoria. Phytother Res 2019;33:2310-8.

38. Gautam SS, Kumar S. The antibacterial and phytochemical aspects of Viola odorata Linn. extracts against respiratory tract pathogens. Proc Biol Sci 2012;82:567-72.

39. Feyzabadi Z, Jafari F, Kamali SH, Ashayeri H, Aval SB, Esfahani MM, et al. Efficacy of Viola odorata in treatment of chronic insomnia. Iran Red Crescent Med J 2014;16:e17511.

40. Ireland DC, Wang CK, Wilson JA, Gustafson KR, Craik DJ. Cyclotides as natural anti-HIV agents. Biopolymers 2008;90: 51-60.

41. Benso B, Rosalen PL, Pasetto S, Marquezin MC, Freitas-Blanco V, Murata RM. Malva sylvestris derivatives as inhibitors of HIV-1 BaL infection. Nat Prod Res 2019:1-6. https://doi.org/10.1080/ 14786419.2019.1619720.

42. Benso B, Rosalen PL, Alencar SM, Murata RM. Malva sylvestris inhibits inflammatory response in oral human cells. An in vitro infection model. PloS One 2015;10:e0140331.

43. Ayrle H, Mevissen M, Kaske M, Nathues H, Gruetzner N, Melzig M, et al. Medicinal plants-prophylactic and therapeutic options for gastrointestinal and respiratory diseases in calves and piglets? A systematic review. BMC Vet Res 2016;12:89.

44. Sadighara P, Gharibi S, Jafari AM, Khaniki GJ, Salari S. The antioxidant and Flavonoids contents of Althaea officinalis $L$. flowers based on their color. Avicenna J Phytomed 2012;2:113-17.

45. Benbassat N, Yoncheva K, Hadjimitova V, Hristova N, Konstantinov S, Lambov N. Influence of the extraction solvent on antioxidant activity of Althaea officinalis L. root extracts. Cent Eur J Biol 2014;9:182-8.

46. Rezaei M, Dadgar Z, Noori-Zadeh A, Mesbah-Namin SA, Pakzad I, Davodian E. Evaluation of the antibacterial activity of the Althaea officinalis L. leaf extract and its wound healing potency in the rat model of excision wound creation. Avicenna J Phytomed 2015;5: 105-12. 
47. Nosal'ova G, Strapkova A, Kardosova A, Capek P, Zathurecký L, Bukovská E. Antitussive action of extracts and polysaccharides of marshmallow (Althea officinalis L., var. robusta). Pharmazie 1992;47:224-6.

48. Šutovská M, Nosál'ová G, Šutovský J, Fraňová S, Prisenžňáková L, Capek P. Possible mechanisms of dose-dependent cough suppressive effect of Althaea officinalis rhamnogalacturonan in Guinea pigs test system. Int J Biol Macromol 2009 Jul 1;45:27-32.

49. Alani B, Zare M, Noureddini M. Bronchodilatory and B-adrenergic effects of methanolic and aqueous extracts of Althaea root on isolated tracheobronchial smooth rat muscle. Adv Biomed Res 2015;4. https://doi.org/10.4103/2277-9175.153905.

50. Cinatl J, Morgenstern B, Bauer G, Chandra P, Rabenau H, Doerr HW. Glycyrrhizin, an active component of liquorice roots, and replication of SARS-associated coronavirus. Lancet 2003;361:2045-6.

51. Wang L, Yang R, Yuan B, Liu Y, Liu C. The antiviral and antimicrobial activities of licorice, a widely-used Chinese herb. Acta Pharm Sin B 2015;5:310-5.

52. Fiore C, Eisenhut M, Krausse R, Ragazzi E, Pellati D, Armanini D, et al. Antiviral effects of Glycyrrhiza species. Phytother Res 2008; 22:141-8.

53. Frattaruolo L, Carullo G, Brindisi M, Mazzotta S, Bellissimo L, Rago V, et al. Antioxidant and anti-inflammatory activities of flavanones from Glycyrrhiza glabra L. (licorice) leaf phytocomplexes: identification of licoflavanone as a modulator of NF-kB/MAPK pathway. Antioxidants 2019;8:186.

54. Kalikar MV, Thawani VR, Varadpande UK, Sontakke SD, Singh RP, Khiyani RK. Immunomodulatory effect of Tinospora cordifolia extract in human immuno-deficiency virus positive patients. Indian J Pharmacol 2008;40:107-10.

55. Alsuhaibani S, Khan MA. Immune-stimulatory and therapeutic activity of Tinospora cordifolia: double-edged sword against salmonellosis. J Immunol Res 2017;2017. https://doi.org/10. $1155 / 2017 / 1787803$.

56. Sharma P, Dwivedee BP, Bisht D, Dash AK, Kumar D. The chemical constituents and diverse pharmacological importance of Tinospora cordifolia. Heliyon 2019;5:e02437.

57. Hussain L, Akash MS, Ain NU, Rehman K, Ibrahim M. The analgesic, anti-inflammatory and anti-pyretic activities of Tinospora cordifolia. Adv Clin Exp Med 2015;24:957-64.

58. Jadhav P, Lal H, Kshirsagar N. Assessment of potency of PC-complexed Ocimum sanctum methanol extract in embryonated eggs against influenza virus (H1N1). Phcog Mag 2014;10:S86-9.

59. Kumar A, Agarwal K, Maurya AK, Shanker K, Bushra U, Tandon S, et al. Pharmacological and phytochemical evaluation of Ocimum sanctum root extracts for its anti-inflammatory, analgesic and antipyretic activities. Phcog Mag 2015;11:S217-24.

60. Mondal S, Varma S, Bamola VD, Naik SN, Mirdha BR, Padhi MM, et al. Double-blinded randomized controlled trial for immunomodulatory effects of Tulsi (Ocimum sanctum Linn.) leaf extract on healthy volunteers. J Ethnopharmacol 2011;136:452-6.

61. Ghoke SS, Sood R, Kumar N, Pateriya AK, Bhatia S, Mishra A, et al. Evaluation of antiviral activity of Ocimum sanctum and Acacia arabica leaves extracts against $\mathrm{H} 9 \mathrm{~N} 2$ virus using embryonated chicken egg model. BMC Complement Altern 2018;18:174.

62. Saini A, Sharma S, Chhibber S. Induction of resistance to respiratory tract infection with Klebsiella pneumoniae in mice fed on a diet supplemented with tulsi (Ocimum sanctum) and clove
(Syzgium aromaticum) oils. J Microbiol Immunol Infect 2009;42: 107-13.

63. Jamshidi N, Cohen MM. The clinical efficacy and safety of Tulsi in humans: a systematic review of the literature. Evid-Based Compl Alt 2017;2017. https://doi.org/10.1155/2017/9217567.

64. Ulasli M, Gurses SA, Bayraktar R, Yumrutas O, Oztuzcu S, Igci M, et al. The effects of Nigella sativa (Ns), Anthemis hyalina (Ah) and Citrus sinensis (Cs) extracts on the replication of coronavirus and the expression of TRP genes family. Mol Biol Rep 2014;41: 1703-11.

65. Koshak AE, Yousif NM, Fiebich BL, Koshak EA, Heinrich M. Comparative immunomodulatory activity of Nigella sativa L. Preparations on proinflammatory mediators: a focus on asthma. Front Pharmacol 2018;9:1075.

66. Forouzanfar F, Bazzaz BS, Hosseinzadeh H. Black cumin (Nigella sativa) and its constituent (thymoquinone): a review on antimicrobial effects. Iran J Basic Med Sci 2014;17:929.

67. Yimer EM, Tuem KB, Karim A, Ur-Rehman N, Anwar F. Nigella sativa L. (black cumin): a promising natural remedy for wide range of illnesses. Evid-Based Compl Alt 2019;2019. https://doi. org/10.1155/2019/1528635.

68. Ghannadi A, Hajhashemi V, Jafarabadi H. An investigation of the analgesic and anti-inflammatory effects of Nigella sativa seed polyphenols. J Med Food 2005;8:488-93.

69. Gilani AH, Aziz N, Khurram IM, Chaudhary KS, Iqbal A. Bronchodilator, spasmolytic and calcium antagonist activities of Nigella sativa seeds (Kalonji): a traditional herbal product with multiple medicinal uses. Pak Med Assoc 2001;51:115-20.

70. San Chang J, Wang KC, Yeh CF, Shieh DE, Chiang LC. Fresh ginger (Zingiber officinale) has anti-viral activity against human respiratory syncytial virus in human respiratory tract cell lines. J Ethnopharmacol 2013;145:146-51.

71. Jin YH, Cai L, Cheng ZS, Cheng H, Deng T, Fan YP, et al. A rapid advice guideline for the diagnosis and treatment of 2019 novel coronavirus (2019-nCoV) infected pneumonia (standard version). Mil Med Res 2020;7:4.

72. Danciu C, Vlaia L, Fetea F, Hancianu M, Coricovac DE, Ciurlea $\mathrm{SA}$, et al. Evaluation of phenolic profile, antioxidant and anticancer potential of two main representants of Zingiberaceae family against B164A5 murine melanoma cells. Biol Res 2015;48:1.

73. Mashhadi NS, Ghiasvand R, Askari G, Hariri M, Darvishi L, Mofid MR. Anti-oxidative and anti-inflammatory effects of ginger in health and physical activity: review of current evidence. Int J Prev Med 2013;4:S36-42.

74. Carrasco FR, Schmidt G, Romero AL, Sartoretto JL, Caparroz-Assef SM, Bersani-Amado CA, et al. Immunomodulatory activity of Zingiber officinale Roscoe, Salvia officinalis L. and Syzygium aromaticum L. essential oils: evidence for humor-and cellmediated responses. J Pharm Pharmacol 2009;61:961-7.

75. Bera K, Nosalova G, Sivova V, Ray B. Structural elements and cough suppressing activity of polysaccharides from Zingiber officinale rhizome. Phytother Res 2016;30:105-11.

76. Townsend EA, Siviski ME, Zhang Y, Xu C, Hoonjan B, Emala CW. Effects of ginger and its constituents on airway smooth muscle relaxation and calcium regulation. Am J Resp Cell Mol 2013;48: 157-63.

77. Jiang ZY, Liu WF, Zhang XM, Luo J, Ma YB, Chen JJ. Anti-HBV active constituents from Piper longum. Bioorg Med Chem Lett 2013;23: 2123-7. 
78. Timbadiya MJ, Nishteswar K, Acharya R, Nariya MB. Experimental evaluation of antipyretic and analgesic activities of Amalakyadi Gana: an Ayurvedic formulation. AYU 2015;36:220-4.

79. Kumar S, Malhotra S, Prasad AK, Van der Eycken EV, Bracke ME, Stetler-Stevenson WG, et al. Anti-inflammatory and antioxidant properties of Piper species: a perspective from screening to molecular mechanisms. Curr Top Med Chem 2015;15:886-93.

80. Sunila ES, Kuttan G. Immunomodulatory and antitumor activity of Piper longum Linn. and piperine. J Ethnopharmacol 2004 Feb 1; 90:339-46.

81. Kaushik D, Rani R, Kaushik P, Sacher D, Yadav J. In vivo and in vitro antiasthmatic studies of plant Piper longum Linn. Int J Pharmacol 2012;8:192-7.

82. Ninave PB, Patil SD. Antiasthmatic potential of Zizyphus jujuba Mill and Jujuboside B.-Possible role in the treatment of asthma. Resp Physiol Neurobi 2019;260:28-36.

83. Mohebbati R, Bavarsad K, Rahimi M, Rakhshandeh H, Rad AK, Shafei MN. Protective effects of long-term administration of Ziziphus jujuba fruit extract on cardiovascular responses in L-NAME hypertensive rats. Avicenna J Phytomed 2018;8:143-51.

84. Mahmood N, Piacente S, Pizza C, Burke A, Khan Al, Hay AJ. The anti-HIV activity and mechanisms of action of pure compounds isolated from Rosa damascena. Biochem Biophys Res Commun 1996;229:73-9.

85. Hajhashemi V, Ghannadi A, Hajiloo M. Analgesic and antiinflammatory effects of Rosa damascena hydroalcoholic extract and its essential oil in animal models. Iran J Pharm Res 2010;9: 163-8.

86. Sharma M, Shakya A, Sharma N, Shrivastava S, Shukla S. Therapeutic efficacy of Rosa damascena Mill. on acetaminopheninduced oxidative stress in albino rats. J Environ Pathol Toxicol Oncol 2012;31:193-201.

87. Verma H, Patil PR, Kolhapure RM, Gopalkrishna V. Antiviral activity of the Indian medicinal plant extract, Swertia chirata against herpes simplex viruses: a study by in-vitro and molecular approach. Indian J Med Microbiol 2008;26: 322-6.

88. Bhargava S, Rao PS, Bhargava P, Shukla S. Antipyretic potential of Swertia chirata Buch Ham. root extract. Sci Pharm 2009;77: 617-24.

89. Lad H, Bhatnagar D. Amelioration of oxidative and inflammatory changes by Swertia chirayita leaves in experimental arthritis. Inflammopharmacology $2016 \mathrm{Dec} ; 24: 363-75$.

90. Rizvi W, Fayazuddin M, Singh O, Syed SN, Moin S, Akhtar K, et al. Anti-inflammatory effect of Fumaria parviflora leaves based on

TNF- $\alpha$, IL-1, IL- 6 and antioxidant potential. Avicenna J Phytomed 2017;7:37-45.

91. Păltinean R, Mocan A, Vlase L, Gheldiu AM, Crișan G, lelciu I, et al. Evaluation of polyphenolic content, antioxidant and diuretic activities of six Fumaria species. Molecules 2017;22:639.

92. Gupta PC, Sharma N, Rao CV. A review on ethnobotany, phytochemistry and pharmacology of Fumaria indica (Fumitory). Asian Pac J Trop Biomed 2012 Aug;2:665-9.

93. Sun Z, Yu C, Wang W, Yu G, Zhang T, Zhang L, et al. Aloe polysaccharides inhibit influenza $A$ virus infection-a promising natural anti-flu drug. Front Microbiol 2018;9:2338.

94. Choi JG, Lee H, Kim YS, Hwang YH, Oh YC, Lee B, et al. Aloe vera and its components inhibit influenza $A$ virus-induced autophagy and replication. Am J Chin Med 2019;47:1307-24.
95. Ho TY, Wu SL, Chen JC, Li CC, Hsiang CY. Emodin blocks the SARS coronavirus spike protein and angiotensin-converting enzyme 2 interaction. Antivir Res 2007;74:92-101.

96. Rezazadeh F, Moshaverinia M, Motamedifar M, Alyaseri M. Assessment of anti HSV-1 activity of Aloe vera gel extract: an in vitro study. J Dent (Shiraz) 2016 Mar;17:49-54.

97. Rahmani AH, Aldebasi YH, Srikar S, Khan AA, Aly SM. Aloe vera: potential candidate in health management via modulation of biological activities. Pharmacogn Rev 2015;9:120-6.

98. Soleymani S, Zabihollahi R, Shahbazi S, Bolhassani A. Antiviral effects of saffron and its major ingredients. Curr Drug Deliv 2018;15:698-704.

99. Karimi E, Oskoueian E, Hendra R, Jaafar HZ. Evaluation of Crocus sativus L. stigma phenolic and flavonoid compounds and its antioxidant activity. Molecules 2010;15:6244-56.

100. Mahmoudabady M, Neamati A, Vosooghi S, Aghababa H. Hydroalcoholic extract of Crocus sativus effects on bronchial inflammatory cells in ovalbumin sensitized rats. Avicenna J Phytomed 2013;3:356-63.

101. Boskabady MH, Gholamnezhad Z, Ghorani V, Saadat S. The effect of Crocus sativus (saffron) on the respiratory system. Trad Exp Evid 2019;1:30-54 29.

102. Pourmasoumi M, Hadi A, Najafgholizadeh A, Kafeshani M, Sahebkar A. Clinical evidence on the effects of saffron (Crocus sativus L.) on cardiovascular risk factors: a systematic review meta-analysis. Pharmacol Res 2019 1;139:348-59.

103. Germano A, Occhipinti A, Barbero F, Maffei ME. A pilot study on bioactive constituents and analgesic effects of MyrLiq ${ }^{\circledR}$, a Commiphora myrrha extract with a high furanodiene content. Biomed Res Int 2017. https://doi.org/10.1155/2017/3804356.

104. Su S, Wang T, Duan JA, Zhou W, Hua YQ, Tang YP, et al. Antiinflammatory and analgesic activity of different extracts of Commiphora myrrha. J Ethnopharmacol 2011;134:251-8.

105. Fatani AJ, Alrojayee FS, Parmar MY, Abuohashish HM, Ahmed MM, Al-Rejaie SS. Myrrh attenuates oxidative and inflammatory processes in acetic acid-induced ulcerative colitis. Exp Ther Med 2016;12:730-8.

106. Ahmad A, Raish M, Ganaie MA, Ahmad SR, Mohsin K, Al-Jenoobi $\mathrm{FI}$, et al. Hepatoprotective effect of Commiphora myrrha against d-GalN/LPS-induced hepatic injury in a rat model through attenuation of pro inflammatory cytokines and related genes. Pharm Biol 2015;53:1759-67.

107. Khalil N, Fikry S, Salama O. Bactericidal activity of Myrrh extracts and two dosage forms against standard bacterial strains and multidrug-resistant clinical isolates with $\mathrm{GC} / \mathrm{MS}$ profiling. $\mathrm{AMB}$ Express 2020;10:21.

108. Alhussaini MS, Saadabi AM, Alghonaim MI, Ibrahim KE. An evaluation of the antimicrobial activity of Commiphora myrrha Nees (Engl.) oleo-gum resins from Saudi Arabia. Res J Med Sci 2015;15:198.

109. Anonymous. The Unani Pharmacopoeia of India. Part - II. New Delhi, India: Government Of India Ministry Of Health And Family Welfare Department Of Ayurveda, Yoga \& Naturopathy, Unani, Siddha And Homoeopathy (Ayush); 2009, vol I. New Delhi.

110. Khan MA, Khan NA, Qasmi IA, Ahmad G, Zafar S. Protective effect of Arque-Ajeeb on acute experimental diarrhoea in rats. BMC Complement Altern Med 2004;4:8.

111. Ranscombe P. Rural areas at risk during COVID-19 pandemic. Lancet Infect Dis 2020 May;20:545. 
112. Shereen MA, Khan S, Kazmi A, Bashir N, Siddique R. COVID-19 infection: origin, transmission, and characteristics of human coronaviruses. J Adv Res 2020 Mar 16;24:91-8.

113. Xu S, Li Y. Beware of the second wave of COVID-19. Lancet 2020 Apr 25;395:1321-2.

114. Yang W, Marr LC. Dynamics of airborne influenza A viruses indoors and dependence on humidity. PloS One 2011;6: e21481.

115. Wilder-Smith A, Chiew CJ, Lee VJ. Can we contain the COVID-19 outbreak with the same measures as for SARS?. Lancet Infect Dis 2020 May;20:e102-7.

116. Cortegiani A, Ingoglia G, Ippolito M, Giarratano A, Einav S. A systematic review on the efficacy and safety of chloroquine for the treatment of COVID-19. J Crit Care 2020 Jun;57: 279-83.

117. Alam MA, Haider N, Ahmed S, Alam MT, Azeez A, Perveen A. Tahlab (Spirulina) and few other medicinal plants having antioxidant \& immunomodulatory properties described in Unani medicine-a review. Int J Pharm Sci 2013;4:4158-64.
118. Alam MA, Ahmed P, Hai U. Geriatric care and concept of antiaging in Unani system of medicine and western perspective: a review. J Gerontol Geriatr Res 2015;4:1-6.

119. Alam MA, Quamri MA, Ayman U, Ansari S, Ahad M. Understanding Humma-e-wabai (epidemic fever) and Amraz-ewabai (epidemic disease) in the light of Unani medicine. J Compl Integr Med 2020:2020-0124. R1.Accepted.

120. Zeinali M, Zirak MR, Rezaee SA, Karimi G, Hosseinzadeh H. Immunoregulatory and anti-inflammatory properties of Crocus sativus (Saffron) and its main active constituents: a review. Iran J Basic Med Sci 2019 Apr;22:334-44.

121. Khan IN, Habib MR, Rahman MM, Mannan A, Sarker MM, Hawlader S. Thrombolytic potential of Ocimum sanctum L., Curcuma longa L., Azadirachta indica L. and Anacardium occidentale L. J Basic Clin Pharm 2011 Jun;2:125-7.

122. Nikhat S, Fazil M. Overview of COVID-19; its prevention and management in the light of Unani medicine. Sci Total Environ 2020 Aug 1;728:138859. 